\title{
EMERGENCE OF KNOWLEDGE COMMONS, RISKS, AND RELEVANCE FOR THE HUMAN-RIGHTS FRAMEWORK
}

\author{
DAVID VILA-VIÑAS
}

\begin{abstract}
The study of common-pool resources (CPRs) has become increasingly important in social sciences. CPRs emphasize a more inclusive use and an institutional and normative community-based approach. However, this approach is exposed to access, sustainability, and democracy risks. This paper shows the interest that the rationality of the institutions for the commons can have for the legal sphere and, particularly, for human rights. Both are characterized by powerful democratic legislation and share concern for meeting the needs of the subjects involved and for the effectiveness of their contents and guarantees.
\end{abstract}

Keywords: commons, knowledge commons, institutions, human rights, ESCR, effectiveness

Summary: 1. The emergence of COMmons. 2. Effectiveness, Risks And VUlnerabilities. 2.1 Access. 2.2 Sustainability. 2.3 Democracy. 2.4 Responses. 3. Legal IMPACt. 3.1 Human-rights approach. 4. Conclusion

\section{THE EMERGENCE OF COMMONS}

Commons made a significant impact on social sciences at the end of the 20th century. In the academic field, the main trigger was the publication of Governing the Commons (Östrom, 1990). This work draws on research conducted in previous decades by the Political Theory and Policy Analysis research group at Indiana University. ${ }^{2}$ The group's research aimed at the functioning of common-pool resources (CPRs) such as aquifers, fisheries or forests. Based on that research, they inferred some general characteristics of the nature of these resources and their institutional functioning. The most important aspect of CPRs is not the object on which they have been established (the well, the forest or the software) or their particular characteristics, but the fact that they have been institutionalized, in other words, their institutional dimension. This implies the existence of a community that has given itself a set of explicit and implicit norms (Hess and Östrom, 2016b: 66), methods of participation and mechanisms of law enforcement. ${ }^{3}$

In political terms, the notion of CPRs or, more loosely, commons, has served to analyze how the property regime has expanded to become the paradigmatic regime of the relationship and availability of things, with a tendency to adopt an absolute character.

\footnotetext{
${ }^{1}$ Adjunct Professor of Philosophy of Law, University of Zaragoza, Spain, (dvila@unizar.es)

${ }^{2}$ There is a database on CPRs and research associated with this group, called the Digital Library of the Commons (https://dlc.dlib.indiana.edu/dlc/).

${ }^{3}$ See Östrom (1990: 90-102) for a more systematic explanation of the principles of CPR operation.
} 
In historical terms, a first process of transition from the commons regime to a private or public property regime - called enclosing - has been noted, particularly in CPRs related to popular economics in the Modern Age (Polanyi, 2001; Laval and Dardot, 2015: 282 and ff.; Federici, 2010).

More recently, the concept of enclosing has been used to analyze a second process, this time focused on knowledge commons (such as science, software, biodiversity or cultural production), ${ }^{4}$ key goods in the knowledge economy (Boyle, 2008, Vila-Viñas and Barandiaran, 2015). Knowledge commons have their own specificities, which imply some analytical consequences, the most relevant being that institutions of the commons do not depend on the nature of the goods on which they are established, although they might be conditioned by their characteristics. ${ }^{5}$ If the analysis is limited to early CPRs — termed traditional commons by Östrom - which tend to be local and to have a strong biophysical component, we might be tempted to think that these institutions are in decline and enclosing is already residual. However, the twentieth-century consolidation of institutions that share features with commons (although with State predominance) and the recent emergence of knowledge commons-based institutions have renewed the scene. Both their contrived configuration and the significant threat of enclosure confirm the legal and political nature of these categories. For instance, the option of establishing intellectual property rights over the use of certain biological forms or genomic characteristics (or regulating these fields in any way) does not depend on the nature of these goods that, together with other social relations, have long existed. However, the novelty lies in a change in the legal-political rationality that allows to specify certain aspects of those goods and either include them as others in the legal traffic or exclude their appropriability to establish other uses.

The expansion of the CPR notion and its renewed relevance is also due to its role in the context of the network society (Castells, 2004) or cognitive capitalism (Moulier-Boutang, 2011), in which knowledge has become the critical factor of labor and market processes. Although the knowledge-commons category is heterogeneous, it shares interesting features with traditional commons. While knowledge commons are often subtractive in nature - the wood taken from the forest by one community member can not be taken by another - "most types of knowledge have, on the other hand, been relatively nonsubtractive. Indeed, the more people that share useful knowledge, the greater the common good" (Hess and Östrom, 2016a: 30). ${ }^{6}$ This does not mean that knowledge commons are exempt from the social dilemmas that accompany these types of goods and their institutional dimension; for instance, CPR institutions should establish contribution

\footnotetext{
${ }^{4}$ Hess and Östrom (2016a: 32) understand knowledge as "all ideas, information and data which are intelligible in whatever form they are expressed or obtained". The differences between data, information and other forms of knowledge are also explored in the paper.

${ }^{5}$ Laval and Dardot (2015: 47-49) argued that there is a risk that the category of commons would be naturalized and thus reduced to a few goods related to archaic economies.

${ }^{6}$ Authors such as Carol Rose (1986) have even put forward the idea of a cornucopia of knowledge commons. According to this characteristic, the more these goods are exploited the more productive they are and the more value they acquire.
} 
systems capable of sustaining their operation and sanctioning systems against behaviors that harm them (Hess and Östrom, 2016a: 38-39). In any event, institutionality and legislation are not a lesser evil for their governance. Neither traditional commons nor knowledge commons are natural commons to preserve, but human institutions to reproduce.

In terms of their biophysical characteristics, the most notable difference is the increasingly digital nature of knowledge commons. ${ }^{7}$ The commonality of these knowledge goods also faces the challenge of establishing institutions for the commons on a broader scale than traditional commons. It is true that some knowledge commons are still local -as a self-training group that teaches courses and runs a small library in a community social center - but many others need to operate on a wider, tending-toward global, scale such as the DOAJ database ${ }^{8}$ or the Linux operating system.

Although this distinction is interesting, knowledge commons are not a completely separate category from the whole of the commons. Laval and Dardot (2015) - and Hardt and Negri (2009) before them- established a framework in which they insist that all commons are interconnected to the extent that they form their own social texture, that is, a set of practices and values differentiated from those of the market (private property rules) and from those of the State (principle of sovereignty rules). Therefore, it is not just a third type of goods, different from the majority of private goods and the minority of public goods, as neoclassic theory has put forward (Vercellone et al., 2015: 10-11). Although this approach is not as widespread and multifaceted as Östrom's, it has the virtue of underlining the political and the conflicting dimension of these institutions. Consequently, in this extensive understanding of commons, the primacy of knowledge commons as a highly differentiated and prevalent category loses strength. For instance, its intangible character is questioned, due to the huge need for biophysical (schools, teachers) or digital (servers, cabling, etc.) infrastructures (Bratton, 2016) and to the biological needs of people that embody that knowledge, such as housing, food or security (Vercellone et al., 2014: 18 and ff.). The analysis of the elements of this second enclosure movement reveals that they are objects with material bases, such as seeds (Dafermos and Vivero-Pol, 2015), biodiverse substances (Golinelli et al., 2015), human bodies (Rosenfeld and Mason, 2013) and physical infrastructures supporting the Internet. In addition, the outputs of these institutions of commons are not only innovations in digital fields or frontier science, but also in social practices and linguistic and managerial skills that form the basis of the expansion of the personal services sector (Morini, 2014; Marazzi, 2011).

\section{EFFECTIVENESS, RISKS AND VULNERABILITIES}

Rather than pre-existing, commons are made, since they are fundamentally a practice of common doing, commoning. ${ }^{9}$ This notion has several implications. Firstly, it

\footnotetext{
${ }^{7}$ This makes Hess and Östrom's initial analyses more complex and incorporates new differences. See Prainsack (2019).

${ }^{8}$ Directory of Open Access Journals. See https://doaj.org/

${ }^{9}$ See Linebaugh (2013: 64). This same immanent characterization of the communal rights leads Linebaugh to differentiate them from the human rights.
} 
emphasizes effectiveness. If institutions are to endure, they must be effective in achieving their objectives within a given and constantly evolving context. Secondly, institutional, regulatory, and organizational issues become paramount. These are features shared by various contemporary approaches to commons. On this consensus, Laval and Dardot (2015: 663) note that institutional activity is not just a managerial-technical task, but a political activity and, as such, subject to a variety of threats and conflicts. Indeed, the popularization of commons has run parallel to the hegemonic progression of neoliberal governmentality. This neoliberal rationality of government has proposed an alternative project to that of traditional and contemporary commons: it has tried to inscribe them in the same logic of appropriability, according to the absolute regime of property (Laval and Dardot, 2015: 109-110), better known as privatization in the political sphere.

This section introduces sources of vulnerability of the commons, with special attention paid to knowledge commons. The following section shows that these risks are shared with those risks impacting the effectiveness of rights, since both commons and rights aim to respond to essential needs. These risks should not be understood as small enclosures and changes in the governance of certain goods, but as part of a governmentality change that proposes replacing basic welfare institutions, such as "social property" (Castel, 2004: 41-43), public services, the social rights of post-war constitutions (Offe, 1994: 127-134) and the emerging knowledge commons by another institutional network and regime of relations with oneself and others (Foucault, 2007: 275 and ff.).

How would a research agenda on the risks faced by commons be configured? Research into the effectiveness of rights, particularly economic, social, and cultural rights (ESCR), can use the violation approach, which focuses on studying the most frequent and significant violations to understand how they actually function and to design guarantees that a normative analysis would not make possible on its own (Chapman, 1996). The inductive method used by Östrom's group established a classification of the most frequent institutional problems and organized them as: a) equity issues, relating to the balance between ownership and contribution to CPRs; b) efficiency issues, relating to the production, management and optimal use of the resource; and c) sustainability issues, relating to the long-term performance of the resource (Hess and Östrom, 2016a: 29). This approach is an adequate starting point to organize risks into three groups: access, sustainability, and democracy issues. ${ }^{10}$

\subsection{Access}

Access problems are related to the possibility of excluding individuals and groups from using and enjoying commons. This is a risk associated with the expansion of appropriability, that is, a management of commons under a property-based regime. For instance, this occurs with the expansion of intellectual property rights over knowledge commons, which promotes the establishment of new forms of exclusion (Prainsack, 2019: 7 and ff.). This does not mean that the perfect regime for all commons is one of unlimited

\footnotetext{
${ }^{10}$ This set of risks is consistent with the fundamental principles that recent research on urban commons have noted, such as universality-inalienability, sustainability and democracy (Méndez de Andes et al., 2019: 1).
} 
open access, which might lead to dynamics of inequal competition and selectivity (Morozov, 2012; Tkacz, 2012) as well as risks for CPR sustainability. It is, therefore, usual for the communities behind commons to establish rules of exclusion or, at least, limited exploitation to prevent such perverse effects. Sometimes those limitations can be inferred from the very characteristics of the common good, for instance, scientific knowledge. Although it could be classified as a CPR, access to its outcomes or participation in scientific production are highly regularized through methodological rules imposed by the scientific community itself (Ahumada, 2012). Nevertheless, the fact that access to CPR depends on certain rules, which are necessary for their own functioning, does not mean they are all admissible in a rights-based approach (e.g., certain experiments are forbidden) nor that they are without consequences for the sustainability of the resource or the general interest.

\subsection{Sustainability}

CPRs that have persisted have been effective in achieving the goals their communities sought, but also in maintaining their sustainability. ${ }^{11}$ In contrast to this situation, feminist approaches to social reproduction have shown how neoliberal governmentality does not consider the relevance and cost of sustainability, thus putting the continuity of different forms of life at risk (Carrasco, 2014; Morini, 2014; Pérez Orozco, 2014; Dalla Costa, 2009). Neoliberal strategies have taken advantage of the intangible and decentralized composition of many knowledge commons to subordinate CPR sustainability to the benefit of intellectual property rights holders (Vila-Viñas and Barandiaran, 2015). This is contrary to the functioning of knowledge. First, it is not possible to extract knowledge completely from the person who embodies it to insert it into a production cycle as a part of capital, as another factor of production and, second, neither is it possible to individualize it entirely in the position of a particular worker who is paid to use their knowledge. As indicated, governmentality of corporative welfare (Rose and Miller, 1992: 23; Vila-Viñas, 2014: 201 and ff) proposed the creation of some major social devices to address these problems and to socialize risks: public education and public health services that could ensure knowledge expansion, transfer systems that could protect in times of labor inactivity and rising wages and a huge proportion of unpaid and subordinated female labor.

Neoliberal governmentality has added strategies of appropriation of commons, usually known as commodification and privatization (Foucault, 2007: 177-179). That expansion of the appropriability of CPR outcomes without an equivalent contribution to

\footnotetext{
${ }^{11}$ See principles illustrated by long-enduring CPR institutions in Östrom (1990: 90-102). As Vercellone et al. (2015: 18) posit, the innovation of knowledge CPRs "recalls ecological and collective problems that were missing from the notions of rivalrousness and non-rivalrousness in consumption. The term commonpool resource makes the ecological problem plain by referring to the equilibrium between the stock and flow necessary to guarantee the reproduction of a resource".

${ }^{12}$ Some data may clarify the context of vulnerability of the young population in Spain. In the last quarter of 2019 , only $18.6 \%$ of young people aged 16-29 were emancipated (at the same time in 2008 , this proportion was $26.1 \%$ ). Development runs parallel to the prices of rental housing, which has risen from $55.7 \%$ to $94 \%$ of a worker's salary during the same period (Source: Injuve. Observatorio de Emancipación). The average age for emancipation in EU is 26 years old and 29 in Spain (Source: Eurostat). The risk of child poverty in Spain was 26.8 in 2018 (Source: ECV, 2008-2018). The average age for having the first child for women in Spain was 31 years old in 2018 (Source: INE).
} 
their renewal involves a risk for the sustainability of knowledge commons. Consequently, although identifying the risk of the ecological collapse of some CPRs is usual, pointing out social and political risks is less so (Vercellone, 2011: 90, 103-5). These risks are shared with those that threaten the effectiveness of social rights in Spain, such as the right to housing or the right to a dignified life for some groups. ${ }^{12}$ Furthermore, if neoliberal governmentality has increased the capture of CPR resources without the corresponding replenishment, the shift to austerity (Blyth, 2013; Baker, 2010) has increased the pressure on these resources, even with the sacrifice of economic profit in favor of preserving the status quo. ${ }^{13}$

\subsection{Democracy}

These access and sustainability risks are related to institutional and democratic risks. As Boyle (2008: 51) noted, if the tradition of intellectual property rights as an exception has shifted to becoming the norm, it is because of some shortcomings in the democratic development of these new regulations. One aspect that is easily forgotten in the description of the enclosing process from a socio-legal perspective is that it not only puts universal access at risk, by allowing exclusions and discriminations based on property rights that tend toward the absolute, but also CPR sustainability, when it leads to resource exploitation that is not compensated by enough contributions to renew it. In addition, these enclosures also involve a risk for autonomous CPR governance. Östrom's group identified the importance of the community that embodies CPRs and its institutional capacity, firstly, to provide rules for self-governance and, secondly, to provide mechanisms to deal with conflicts and to strengthen compliance with these rules. In this regard, if a CPR becomes appropriable, it means any holder of the property rights can manage it exclusively. On a resource scale, this centralizes responsibilities that were formerly distributed throughout the community, even if there was a certain level of differentiation and specialization in how they were performed. On an ecosystem scale based on knowledge commons, such as the contemporary knowledge economy, this hierarchizes its functioning. For instance, the acronym GAFA $^{14}$ now not only refers to the main economic stakeholders, but also to political stakeholders capable of deciding on the form and effects of communications or cultural consumption (Zuboff, 2019; Cancela, 2019; Morozov, 2018).

A similar situation is observed in science, which is also a knowledge commons and the object of a right (Morgera, 2015; Plomer, 2015; Shaheed, 2014). Most evident violations are due to the discrimination of some populations regarding their access to some medical treatments or to water purification methods, but their continued exclusion from scientific knowledge (e.g., by a reduction in public investment in science or by a

\footnotetext{
${ }^{13}$ Before the austerity approach became widespread in many peripheral states, Dean (2003: 167-170) describes it as reflexive governmentality, where the primary objective is the security and stability of government and all other objectives are subordinated.

${ }^{14}$ Information on the technological sector refers to GAFA or Big Four (Google, Apple, Facebook, and Amazon) and also GAFAM or Big Five, including Microsoft, to refer to these major stakeholders.
} 
concentration of patents) has an effect on their possibilities to direct scientific knowledge in accordance with their values and interests, something that it is usually reflected in constitutional texts or in international covenants on rights. This introduces the risk that knowledge is no longer a mechanism of emancipation but a mechanism of domination (Laval and Dardot, 2015: 254-5; Shaver, 2015).

\subsection{Responses}

The social-corporate governmentality of welfare generated its own set of preventions regarding these risks, that is, increasing access to basic goods through state solidarity systems and public services, along with contribution devices that allowed for their expansion. Both production and life cycles were organized around corporation culture (Boltanski and Chiapello, 2002), sexual division of labor (Fink, 2001; Lewis, 1997) and state bureaucracy development for the management of these welfare arrangements (Rose, 1996: 46). This set of welfarist solutions returns with force when the neoliberal or austere enclosing movement is at its most severe.

In spite of this, the commons tradition has been reluctant to an exclusively statebased response, either due to its liberal roots (such as Östrom's group), its cooperativist ${ }^{15}$ and municipalist tradition (Restakis, 2015), or the pragmatic need to balance the capture power of the private sector (Horel, 2019) and of prevalent groups in the State (Jessop, 2008; Vila-Viñas, 2014: 53). These positions underscore the leadership of communities and the progressive democratization of social property managed by the State, either in the form of welfare devices or of public services. These critical approaches also evidence the existence of a fundamental division between public and private in our political imaginary. When principles of access, sustainability and democracy have been extended to private goods, justifications about the antagonism between economic efficiency and democratic management often emerge. Based on the greater importance of commons in the knowledge economy, only recently has the relevance of the commons-based production regimes (Benkler, 2006) increased, that is, a production where "no one uses exclusive rights to organize effort or capture its value, and when cooperation is achieved through social mechanisms other than price signals or managerial directions" (Benkler, 2004: 1110).

In a welfare regime, the response to these and other social risks was organized around the opposition between commodified and de-commodified spheres. In the latter, the right to access essential goods was guaranteed for some social groups (Esping-

\footnotetext{
${ }^{15}$ From this approach, this government, built over the praxis of the common (Laval and Dardot, 2015: 266) should be differentiated from the extremes of pure sovereignty and simple management: "thinking in terms of a collective practice related with the use of the unavailable. Neither government nor management, but a collective active use through which everyone participates in the coproduction of non-state legal norms" (Laval and Dardot, 2015: 306).

${ }^{16}$ Most critical approaches to the State, such as Laval and Dardot (2015), equate the political effects of market and State rationality. In the framework proposed by this paper, this identification is incompatible with the constitutional-positivist systems of rights. As a result, the framework or structuring of the public and the commons will be used more often than market rationality and the absolute character of property rights.
} 
Andersen, 2007). Based on a commons approach, the opposition would not be organized between market and State rationalities. The most usual opposition would be between market rationality (organized around an absolute notion of property rights) and commons rationality. ${ }^{16}$ This approach would change the view of the risks of access, sustainability and democracy, which are risks shared between the commons and the de-commodified sphere in welfare systems. This would also allow for a more realistic response to current rights violations.

\section{LEGAL IMPACT}

Since the commons approach became popular in politics and academia, several proposals have tried to use it in the legal field. The best known, mainly from US Law Schools, exposed the extent of intellectual property rights, in parallel to the emergence of the field of information and communication technologies (Boyle, 2008; Harvey, 2007: 6465; Lessig, 2004; Bollier, 2003). At the same time, they explored alternative regulations of property rights over knowledge goods that were the subject of this second enclosures movement. Consequently, intellectual property rights compatible with principles of commons were designed in the fields of cultural and scientific production (as creative commons or copyleft licenses), of software (Lessig, 2006), or of hardware (Pearce, 2014; Lazalde et al., 2015). A common-based production system was also presented (Benkler, 2006), so it could serve as an alternative to production organization that is increasingly based on closed intellectual property rights.

Research conducted by constitutional law was added to these alternatives offered mainly by private law. The relevance of law as the fabric of the network of plural social relations was underlined based on the social law tradition (Gurvitch, 2005). The issue was knowing the role the political rationality of commons could play in that task of improving not only the governance of certain goods and productive processes, but also of the social whole and its political dimension. To this end, spaces of local democracy have been the main field of research, hand in hand with processes of co-government of public services, ${ }^{17}$ in accordance with the subsidiarity principle. ${ }^{18} \mathrm{~A}$ recent example of this approach is the recovery of privatized services under a new logic that is not exclusively public (Cangelosi, 2019: 80). On a broader scale, the main object of criticism has been the expansion of an

\footnotetext{
${ }^{17}$ Cases in the Emilia-Romagna region are well known, where a management system of some public services by entities of social and solidarity economy was chosen (Restakis, 2015), and democratization processes of psychiatric institutions were implemented (Basaglia, 1972).

${ }^{18}$ In the public management sphere, this principle proposes that the community directly manage a service or public resource where possible, while the state should only intervene when direct management by the community is not possible (Restakis, 2015: 604 and ff.).

${ }^{19}$ See Vercellone et al., 2015: 4-5: "Moreover, from the concrete experiences analyzed here, the idea emerges that the concept of common goods can constitute a concrete alternative, and that includes on a legal footing [Rodotà Commission]. Therefore, the common is the product of a social and institutional structure that demonstrates forms of governing and social co-operation that guarantee its production, reproduction and spread. The new institutions of the common that emerge from these constituent practices constitute a general principle of self-governance of society and self-organization of social production, proposing a new division between common, public and private".
} 
absolute property right (Laval and Dardot, 2015: 529 and ff.; Hardt and Negri, 2009: 3 and ff.), which has become a material limit for the effectiveness of our human-rights systems. These approaches, as a whole, have generated a pluralization of the legal field, introducing a common realm between the classic public (State-sovereignty) and private (individualproperty) dichotomy. ${ }^{19}$ It is a new realm linked to the ecological one and its inappropriable nature (Mattei, 2011: 10-12), in contrast to the "fundamental structure [of] the rule of a subject (an individual, a company, the government) over an object (a private good, an organization, a territory)" (Mattei, 2011: 6), which has prevailed until now.

One thread that could link the concept of commons with our legal traditions would be custom. Some historical examples, such as the English Magna Carta, and, in particular, the Charter of the Forest, of 1225, recognize pre-existing institutions of the commons, with their rights nested (Linebaugh, 2008). Based on objectivist and iusnaturalist perspectives of the legitimacy of rights, the episodes of rights recognition in positive legal norms would be the legal consolidation of legitimate and legally relevant pre-existing practices (Pérez Luño, 2013: 58 and ff.). ${ }^{20}$ Within the framework of this paper, the interest in custom stems from its democratic legitimacy, as a repeated practice with a general awareness of its legal enforceability. However, from a democratic perspective, the main feature of commons is their institutional and normative character. As noted above, one of the most consistent principles that Östrom's group found in the analyzed CPR (Östrom, 1990: 90-102) was the creation of the rules of operation by the communities behind the CPRs. These rules were later recognized by the external authority. Therefore, both CPR creation and continuity are not spontaneous and, instead, obligations and legal links between the members of their communities are very important (Laval and Dardot, 2015: 173). All this brings to light the political and institutional dimension of these resources in contrast to the activity of mere management. CPRs are institutions capable of producing norms from certain sets of practices and conflicting relationships with alternative strategies for governing those resources. ${ }^{21}$

This configuration of commons has two legal consequences. First, by highlighting the institutional dimension, ${ }^{22}$ the relational aspects of legal practice are also emphasized. The starting point is no longer the autonomous subject that uses the world or things in an abstract

\footnotetext{
${ }^{20}$ Although it is not the main object of their research, Laval and Dardot (2015: 352 and ff.) criticize the political effects of this connection between customs and commons because: 1) it does not reflect the process of formation of some commons, such as recent knowledge commons; 2) customary norms arise from a particular network of power relationships, which are difficult to translate into the present; and 3) they are not necessarily in line with the principles of the common, and, to show that, they point to succession law, which they define as an obstacle for the institutions of the common.

21 'Unlike 'management', 'government' assumes conflicts and seeks to overcome them through a decision concerning the rules. Instituting praxis is, therefore, a practice of governing the commons through the conflicts that give them life" (Laval and Dardot, 2015: 663).

${ }^{22}$ In their conclusions, Laval and Dardot (2015: 662-663) maintain a concept of commons quite separate from the more extended meaning as common goods or, as argued in this paper, as institutions of the commons, close to a CPR notion. Although it is an interesting concept because it underlines some characteristics noted in this paper, it is far removed from the general meaning of these concepts, both in legal and political spheres, and is thus less useful.
} 
manner, in accordance with the modern subject-nature division, it is rather an institution formed by a practice of a community of interdependent subjects operating in a given context. This context is sometimes local, such as the running of an irrigation system, and sometimes global, such as the evolution of a scientific discipline. At the same time, institutions are never isolated, but function in a relational manner, in accordance with the induced features and conditions of their ecosystem, that is, based on immanent normativeness.

Second, this institutional life is dynamic. CPRs are artificial and there is not an obligation to sustain them; rather, it depends on their usefulness for the objectives of the community that embodies them. Based on this perspective, the attention paid by legal positivism when a legal norm is enacted becomes less important and, instead, the focus shifts to the changes in the effectiveness of existing norms. These are adapted as the environment evolves, either implicitly or explicitly, by developing new more specific norms, resolving conflicts and allocating sanctions and rewards; that is the reason why the prevalent legal form of CPR governance is made up of principles rather than rules (Prieto Sanchís, 1996). This legal tool makes it possible, firstly, to establish the translation of the community's material values and goals and, secondly, to serve as a hermeneutic criterion so that daily CPR governance can adapt to changes. It is, therefore, a dynamic concept in which the efficacy of norms and guarantee mechanisms become key elements.

\subsection{Human-rights approach}

This paper proposes that the commons approach has elements akin to the human-rights approach. Thus, the development and use of the former can enhance some aspects of the latter that will be explained in this section: 1) it strengthens the focus on the effectiveness of the rights; 2) in particular, on their factual dimension, that is, the dimension related to specific violations aimed at designing more appropriate and effective strategies and guarantees; 3) the commons approach reduces the distance and hierarchy between civil and political rights and economic, social and cultural ones; and 4) all this improves the legitimacy of the legal system as a whole.

Regarding the first issue, it should be noted that the commons are sets of practices that must find their own normative path to becoming institutionalized. Consequently, the distance between the normative and descriptive dimension is reduced. In a process that is analogous to the recognition of new rights, norms of the institutions of the commons respond to immanent needs that are consolidated. When the democratic principle is also operating properly, the whole community participates in fulfilling these rules. ${ }^{23}$ Due to the energy invested in the development and adjustment of norms and their relevance for institutional sustainability (Laval and Dardot, 2015: 172, 419 and ff.), it is foreseeable that communities will pay attention to their efficacy, to the most frequent violations and

\footnotetext{
${ }^{23}$ Although many political stories show both the institutions of the common and those ruled by the ownership principle as an isolated world, in fact both institution types share one world. Researching the flexibilization that this interdependence imposes on implementing the institutional principles of commons is needed, such as the flexibilization of the democratic principle in social and solidarity economy, with the introduction of some hierarchies within commons governance.
} 
to when these are no longer isolated situations but reflect systematic vulnerabilities. Risk management around problems of access, sustainability and democracy, which have been outlined in the previous section, has aimed to show that certain risks and vulnerabilities are shared between commons institutions and human rights, particularly ESCR.

Concerning the second issue, this strategic approach has resulted in the importance of techniques to control and guarantee the effectiveness of the main institutional principles (similar to human rights for society as a whole), and establishing the necessary claiming and self-execution mechanisms. ${ }^{24}$ The commons institutional perspective operates on the basis of a flexibilization of the contours separating those who establish the norms, those who apply them and those bound by them or who claim judicial protection in the event of a violation: an institutional development space is created to make commons (commoning) and rights.

Relating to the third issue, the distance and the hierarchy between civil and political rights, on the one hand, and ESCR, on the other, are blurred.$^{25}$ Indeed, as noted above, the effectiveness of social rights such as access to education, health or science, together with a progressive system of fiscal contributions for their sustainability, is at the heart of the development of knowledge commons, which are conditions of the current knowledge economy. ${ }^{26} \mathrm{~A}$ distinction between these two groups is rather less useful in relation to problems and strategies posed by commons, as some examples show. In the case of science, the impossibility of accessing this resource not only harms their economic status, but also the free development of their personality and their dignity. Women's unequal access to social prevention devices, such as a pension system, ${ }^{27}$ not only affects their economic status, but also their independence, for instance in accessing a life free of violence (Bodelón, 2014; Meyersfeld, 2012). It is naive to think that the damage suffered by the planet will impact only on the social and economic aspects of life, without conditioning civil and political rights, as is evident in the face of any major public health alarm. Although this pragmatic nature is found at the heart of commons, the way of addressing institutional risks generates chains of equivalence between different

\footnotetext{
${ }^{24}$ Aparicio (2017) has criticized the lack of attention that research has paid to mechanisms of self-execution of rights. Consequently, it might be interesting to recall the existing lines of exclusion in the access to court. As Mattei (2011: 5) has noted: "Furthermore, it has always been problematic for the commons to find someone that would represent them in court, by suing those who tried to seize them. Both historically and today, those who benefit most from the commons are not 'owners' in the technical sense, but usually poor farmers (or today young internet surfers) with no means of getting into the court system".

${ }^{25}$ See Gómez Isa (2011) and Calvo García (2016) about how this hierarchy has worked in recent contexts of economic crises.

${ }^{26}$ As Vercellone et al. (2015: 31) state: "the increase in the part of capital called intangible is closely linked to the development of the institutions and collective services of welfare. In particular, it should in fact be emphasised how is actually the expansion of the collective welfare services that has allowed the development of mass education, carrying out a key role in the formation of what we can call collective intelligence or widespread intellectuality: it is in fact the latter, widespread intellectuality that explains the most significant part of the increase in the capital referred to as intangible which, as is emphasised, today represents the essential element of a territory's potential growth and competitiveness".

${ }^{27}$ The Spanish gender gap in retirement pensions has reached 34.6\%, which means that women earn on average almost $€ 6,000$ less per year than men per year for this item (UGT, 2019).

${ }^{28}$ See Laval and Dardot (2015: 524): "politics of the common aims at the reorganization of the social by substituting use rights for the principle of property as the juridical lever of social and political transformation".
} 
spheres, underlining their strategic value: claims for access to goods include the right to participate in their governance and to determine the norms that will help them endure and evolve (Laval and Dardot, 2015: 121-122), for instance, how commons question the extension of property rights as absolute since modernity. By linking access to property with freedom, independence and, thus, dignity, liberalism showed that rights are integral (Locke, 1990 [1690]). As happens in commons, the right to access is a right to participate in the governance of their institutions, on condition that it is not an absolute right, but part of a bundle of rights that form an interdependent institutionality ${ }^{28}$ Consequently, violations in any of their dimensions (social or political) would put at risk not only one aspect of a person's rights, but the inter-institutional whole. Concerning the third issue, all this explains why using new categories, such as commons, might result in a relegitimization of contemporary legal categories and the functioning of the legal, political, and social order.

\section{Conclusions}

In recent decades, the study of CPRs has become increasingly relevant within social sciences. It has also been updated with the inclusion of knowledge commons. This concept emphasizes more inclusive use of resources and, above all, a normativeness and institutionality built by their own communities. In short, the notion of commons does not refer so much to a resource with certain characteristics as to a set of practices (commoning) aimed at raising institutions of the commons.

Of course, under the hegemony of neoliberal and, more recently, austerity-based governmentalities, these institutions face risks. This paper has sought to organize these risks in terms of access, sustainability, and democracy. In a sense, contemporary commons risks, in their second enclosing movement, are shared with the risks facing the effectiveness of human rights, particularly ESCR.

This paper proposes that the commons approach has elements akin to the humanrights approach. Consequently, the development and use of commons can enhance the human-rights approach in some aspects: 1) it strengthens the focus on the rights' effectiveness; 2) in particular, on their factual dimension, that is, the dimension related to specific violations aimed at designing more appropriate and effective strategies and guarantees; 3) the commons approach reduces the distance and hierarchy between civil and political rights and economic, social and cultural ones; and 4) all this improves the legitimacy of the legal system as a whole.

\section{REFERENCES}

AHUMADA CANABES, M. A. (2012) La libertad de investigación científica: panorama de su situación en el constitucionalismo comparado y en el Derecho Internacional. Revista chilena de derecho, 39(2), 411-445.

APARICIO WILHELMI, M. (2017, abril 18) ¿Es posible un uso contrahegemónico del derecho? La Revolución jurídica de los bienes comunes, Barcelona. http://lahidra. net/la-revolucion-juridica-de-los-bienes-comunes/. 
BAKER, D. (2010) The Myth of Expansionary Fiscal Austerity (CEPR Reports and Issue Briefs N. ${ }^{\circ} 23$; p. 14). Center for Economic and Policy Research. https://ideas. repec.org/p/epo/papers/2010-23.html.

BASAGLIA, F. (1972) La institución negada: informe de un hospital psiquiatrico (2a ed.). Barral.

BENKLER, Y. (2004) Commons-Based Strategies and the Problems of Patents. Science, 305(5687), 1110-1111. Disponible.

BENKLER, Y. (2006) The Wealth of Networks: How Social Production Transforms Markets and Freedom. Yale University Press.

BLYTH, M. (2013) Austerity: The History of a Dangerous Idea. Oxford University Press.

BODELÓN, E. (2014) Violencia institucional y violencia de género. Anales de la Cátedra Francisco Suárez, 48, 131-155.

BOLLIER, D. (2003) Silent Theft. The Private Plunder of our Common Wealth. Routledge.

BOLTANSKI, L., and CHIAPELLO, E. (2002) El nuevo espíritu del capitalismo (M. Pérez Colina, A. Riesco, and R. Sánchez Cedillo (trads.), Madrid, Akal.

BOYLE, J.(2008)The Public Domain: Enclosing the Commons of the Mind. Yale University Press; BASE. https://scholarship.law.duke.edu/faculty_scholarship/2708/\#?.

BRATTON, B. H. (2016) The Stack. On Software and Sovereignty. MIT Press.

CALVO GARCÍA, M. (2016) Derechos sociales : algunas propuestas para seguir avanzando en tiempos de incertidumbre. En M. Abad Castelos, M. C. Llamazares Calzadilla, and M. E. Rodríguez Palop (Eds.), Políticas económicas y derechos sociales (pp. 145-173). Dykinson.

CANCELA, E. (2019) Despertar del sueño tecnológico. Crónica sobre la derrota de la democracia frente al capital. Akal.

CANGELOSI, E. (2019) A definition of the commons between human rights, resistance and social change. En T. Haller, T. Breu, T. De Moor, C. Rohr, and H. Znoj (Eds.), The Commons in a Glocal World. Cglobal Connections and Local Responses (p. 501). Routledge.

CARRASCO BENGOA, C. (2014) Economía, trabajos y sostenibilidad de la vida. En Y. Jubeto Ruiz and M. Larragaña Sarriegi (eds.), Sostenibilidad de la vida. Aportaciones desde la Economía Solidaria, Feminista y Ecológica (pp. 27-42). UPV; REAS.

CASTEL, R. (2004) La inseguridad social : ¿qué es estar protegido? (V. Ackerman (trad.)). Manantial.

CASTEllS, M. (Ed.). (2004) The Network Society: A Cross-Cultural Perspective. Edward Elgar.

CHAPMAN, A. R. (1996) Violations Approach. Human Rights Quarterly, 18(1), 23-66. 
DAFERMOS, G., y VIVERO-POL, J. L.(2015)Agroalimentación: Sistema agroalimentario abierto y sustentable en Ecuador. En D. Vila-Viñas y X. E. Barandiaran (eds.), Buen Conocer - FLOK Society. Modelos sostenibles y politicas públicas para una economía social del conocimiento común y abierto en el Ecuador (pp. 345400). IAEN-CIESPAL - aLabs. http://book.floksociety.org/ec/2/2-1-sistemaagroalimentario-abierto-y-sustentable-en-ecuador.

DALLA COSTA, M. (2009) Familia, política de bienestar y Estado entre progresismo y New Deal. En M. Dalla Costa (Ed.), Dinero, perlas y flores en la reproducción feminista (pp. 151-251). Akal.

DEAN, M. (2003) Governmentality: power and rule in modern society (1st, repr). Sage.

ESPING-ANDERSEN, G. (2007) Children in the welfare state. En G. Esping-Andersen (ed.), Family formation and family dilemmas in contemporary Europe (pp. 223263). Fundación BBVA.

FEDERICI, S. (2010) Calibán y la bruja. Mujeres, cuerpos y acumulación originaria (V. Hendel and S. Touza (trads.)). Traficantes de Sueños. http://www.traficantes.net/ libros/caliban-y-la-bruja.

FINK, J. (2001) Silence, absence and elision in analyses of «the family» in European social policy. En J. Fink, G. Lewis, and J. Clarke (eds.), Rethinking European Welfare (pp. 163-180). Sage.

FOUCAULT, M. (2007) Nacimiento de la biopolítica. Curso en el Collège de France (1978-1979). FCE.

GOLINELLI, S., VEGA-VILLA, K., y VILLA-ROMERO, J. F. (2015) Biodiversidad: Ciencia ciudadana, saberes ancestrales y biodiversidad aplicada en la economía social del conocimiento. En D. Vila-Viñas y X. E. Barandiaran (eds.), Buen Conocer - FLOK Society. Modelos sostenibles y políticas públicas para una economía social del conocimiento común y abierto en el Ecuador (pp. 345-396). IAEN - CIESPAL - aLabs. https://book.floksociety.org/ec/2-2-biodiversidadciencia-ciudadana-saberes-ancestrales-y-biodiversidad-aplicada-en-la-economiasocial-del-conocimiento/.

GÓMEZ ISA, F. (2011) The Reversibility of Economic Social and Cultural Rights in Crisis Contexts. Working Papers HURI-AGE, 1, 1-10.

GURVITCH, G. (2005) La idea del Derecho social : noción y sistema del Derecho social : historia doctrinal desde el siglo XVII hasta el fin del siglo XIX (J. L. Monereo Pérez and A. Márquez Prieto (trads.)). Comares; Derecho.

HARDT, M. and NEGRI, A. (2009) Commonwealth. The Belknap Press of Harvard University Press.

HARVEY, D. (2007) A brief history of neoliberalism: $1^{\mathrm{a}}$ reimp. Oxford University Press.

HESS, C. and ÖSTROM, E. (2016a) Introducción: una visión general de los bienes comunes del conociiento. En C. Hess and E. Ostrom (eds.), and P. Carbajosa Pérez, D. Escribano Riera, Á. Ferrero, F. Orobón, and C. Tulbure (trads.), Los bienes 
comunes del conocimiento (pp. 27-50). Traficantes de Sueños, IAEN; Disponible. https://www.traficantes.net/libros/los-bienes-comunes-del-conocimiento.

HESS, C. and ÖSTROM, E. (2016b) Un marco de análisis de los bienes comunes del conocimiento. En C. Hess and E. Ostrom (eds.), and P. Carbajosa Pérez, D. Escribano Riera, Á. Ferrero, F. Orobón, and C. Tulbure (trads.), Los bienes comunes del conocimiento (pp. 65-104). Traficantes de Sueños, IAEN; Disponible. https:// www.traficantes.net/libros/los-bienes-comunes-del-conocimiento.

HOREL, S. (2019) Lobbytomía: cómo los grupos de presión envenenan nuestras vidas y la democracia (L. Sancho (trad.)). Morata.

JESSOP, B. (2008) State power: a strategic relational approach. Polity Press.

LAVAL, C. and DARDOT, P. (2015) Común. Ensayo sobre la revolución en el siglo XXI (A. Díez (trad.)). Gedisa.

LAZALDE, A., J. TORRES and D. VILA-VIÑAS. (2015) Hardware: ecosistemas de innovación y producción basados en hardware libre. En D. Vila-Viñas y X.E. Barandiaran (eds.), Buen Conocer - FLOK Society. Modelos sostenibles y políticas públicas para una economía social del conocimiento común y abierto en el Ecuador, pp. 695-728. Quito, Ecuador: IAEN - CIESPAL - aLabs. http://book. floksociety.org/ec/4/4-1-hardware-ecosistemas-de-innovacion-y-produccionbasados-en-hardware-libre.

LESSIG, L. (2004) Free culture: How big media uses technology and the law to lock down culture and control creativity. Penguin.

LESSIG, L. (2006) Code and Other Laws of Cyberspace (Version 2.0). Basic Books.

LEWIS, J. (1997) Gender and welfare regimes: further thoughts. Social Politics, 4(2), 160-177.

LINEBAUGH, P. (2008) The Magna Carta Manifesto. Liberties and Commons for All. University of California Press.

LINEBAUGH, P. (2013) El manifiesto de la Carta magna: Comunes y libertades para el pueblo. Traficantes de Sueños.

LOCKE, J. (1990) Segundo tratado sobre el gobierno civil. Alianza.

MARAZZI, C. (2011) Capital and Affects. The Politics of the Language Economy (G. Mecchia (trad.)). Semiotext(e).

MATTEI, U. (2011) The State, the Market, and some Preliminary Question about the Commons (text N. ${ }^{\circ}$ 1-11). International University College of Turin. https:// EconPapers.repec.org/RePEc:iuc:rpaper:1-11.

MÉNDEZ DE ANDÉS ALDAMA, A., HAMOU, D. and APARICIO WILHELMI, M. (2019) Códigos Comunes. Herramientas jurídicas para comunalizar la ciudad y democratizar lo público. Observatorio DESC. https://observatoridesc.org/ es/codigos-comunes-herramientas-juridicas-para-comunalizar-ciudad-ydemocratizar-publico.

MEYERSFELD, B. (2012) Domestic Violence and International Law. Hart. 
MORGERA, E. (2015) Fair and Equitable Benefit-Sharing at the Cross-Roads of the Human Right to Science and International Biodiversity Law. Laws, 4, 803-831. https://doi.org/https://doi.org/10.3390/laws4040803.

MORINI, C. (2014) Por amor o a la fuerza. Feminización del trabajo y biopolítica del cuerpo (J. M. Gual Bergas (trad.)). Traficantes de Sueños. http://www.traficantes. net/libros/por-amor-o-la-fuerza.

MOROZOV, E. (2012) The Net Delusion. The Dark Side of Internet Freedom. Public Affairs.

MOROZOV, E. (2018, abril 1) After the Facebook scandal it's time to base the digital economy on public $\mathrm{v}$ private ownership of data. The Guardian. https://www. theguardian.com/technology/2018/mar/31/big-data-lie-exposed-simply-blamingfacebook-wont-fix-reclaim-private-information.

MOULIER-BOUTANG, Y. (2011) Cognitive Capitalism. Polity Press.

OFFE, C. (1994) Legitimidad versus eficiencia. En J. Keane and A. Escohotado (Eds.), Contradicciones en el estado del bienestar (pp. 117-134). Alianza Editorial.

ÖSTROM, E. (1990) Governing the commons: The evolution of institutions for collective action. Cambridge university press.

PEARCE, J. M. (2014) Open-Source Lab. How to Build Your Own Hardware and Reduce Research Costs.

PÉREZ LUÑO, A. E. (2013) Los derechos fundamentales (11 a ed.). Tecnos.

PÉREZ OROZCO, A. (2014) Subversión feminista de la economía. Aportes para un debate sobre el conflicto capital-vida. Traficantes de Sueños. http://www.traficantes.net/ libros/subversion-feminista-de-la-economia.

PLOMER, A. (2015) Patents, Human Rights and Access to Science. Edward Elgar.

POLANYI, K. (2001) The Great Transformation: The Political and Economic Origins of Our Time (2nd ed.). Beacon Press.

PRAINSACK, B. (2019) Logged out: Ownership, exclusion and public value in the digital data and information commons. Big Data \& Society, 1-15. https://doi. org/10.1177/2053951719829773.

PRIETO SANCHÍS, L. (1996) Diez argumentos a propósito de los principios. Jueces para la democracia, 26, 41-49.

RESTAKIS, J. (2015) Institucionalidad: sociedad del conocimiento, economía social y partner state. En D. Vila-Viñas y X.E. Barandiaran (eds.), Buen Conocer - FLOK Society. Modelos sostenibles y políticas públicas para una economía social del conocimiento común y abierto en el Ecuador, pp. 479-550. Quito, Ecuador: IAEN - CIESPAL - aLabs. http://book.floksociety.org/ec/3/3-2-institucionalidadsociedad-del-conocimiento-economia-social-y-partner-state.

ROSE, C. (1986) The Comedy of the Commons: Custom, Commerce, and Inherently Public Property. The University of Chicago Law Review, 53(3), 711. https://doi. org/10.2307/1599583. 
ROSE, N. (1996) Governing «advanced» liberal democracies. En A. Barry, T. Osborne and N. Rose (eds.), Foucault and political reason. Liberalism, neo-liberalism and rationalities of government (pp. 37-64). UCL Press.

ROSE, N. and Miller, P. (1992) Political power beyond the State: problematics of government. The British Journal of Sociology, 43(2), 172-205.

ROSENFELD, J. A. and MASON, C. E. (2013) Pervasive sequence patents cover the entire human genome. Genome Medicine, 5, 27. https://doi.org/10.1186/gm431.

SHAHEED, F. (2014) Report on the Copyright Policy \& the right to science \& culture (Special rapporteur in the field of cultural rights A/HRC/28/57.). United Nations General Assembly; Human Rights Council.

SHAVER, L. (2015) The Right to Science: Ensuring that Everyone Benefits from Scientific and Technological Progress. European Journal of Human Rights, 4, 411-443. https://doi.org/10.2139/ssrn.2564222.

TKACZ, N. (2012) From open source to open government: a critique of open politics. Ephemera: Theory and Politics in Organization, 12(4), 386-405.

UGT. (2019) Brecha salarial en las pensiones. La discriminación salarial más allá de la jubilación (p. 30). UGT. https://www.ugt.es/sites/default/files/informe_pensiones mujer-ok.pdf.

VERCELLONE, C. (2011) Trabajo, distribución del ingreso y valor en el capitalismo cognitivo. Una perspectiva histórica y teórica. En C. Vercellone (Ed.), Capitalismo cognitivo. Renta, saber y valor en la época posfordista (pp. 83-113). Prometeo.

VERCELLONE, C., BRIA, F., FUMAGALLI, A., GENTILUCCI, E., GIULIANI, A., GRIZIOTTI, G. and VATTIMO, P. (2015) D3. 2-Managing the commons in the knowledge economy. Decentralised Citizens Engagement Technologies (K. Amstrong (ed.)). UE, CES, NESTA, D-Cent. https://www.nesta.org.uk/report/dcent-managing-the-commons-in-the-knowledge-economy/.

VILA-VIÑAS, D., and X.E. BARANDIARAN, X.E. (eds.) (2015) Buen Conocer - FLOK Society. Modelos sostenibles y políticas públicas para una economía social del conocimiento común y abierto en el Ecuador. Quito: CIESPAL - IAEN - aLabs. http://book.floksociety.org/ec/.

VILA-VIÑAS, D. (2014) La gobernabilidad más allá de Foucault. Un marco para la teoría social y política contemporáneas. Zaragoza: Prensas Universitarias de Zaragoza.

ZUBOFF, S. (2019) The Age of Surveillance Capitalism. The Fight for a Human Future at the New Frontier of Power. Public Affairs.

Received: May $25^{\text {th }} 2020$

Accepted: August $14^{\text {th }} 2020$ 